\title{
Hypolipidemic Activity of Tetracarpidium conophorum (African walnut) Seed Oil and Its Mechanism of Action
}

\section{(ㄷ)(요 $\odot$}

Authors

Kelly Oriakhi ${ }^{1}$, Patrick Uadia²

\section{Affiliations}

1 Department of Medical Biochemistry, School of Basic Medical Sciences, University of Benin, Benin City, Nigeria

2 Department of Biochemistry, Faculty of Life Sciences, University of Benin, Benin City, Nigeria

\section{Key words}

hyperlipidemia, African walnut, Tetracarpidium conophorum, Euphorbiaceae Cholesterol, gas chromatography-mass spectrometric technique

$\begin{array}{ll}\text { received } & 12.05 .2020 \\ \text { revised } & 16.11 .2020 \\ \text { accepted } & 24.11 .2020\end{array}$

Bibliography

Planta Med Int Open 2020; 7: e170-e178

DOI 10.1055/a-1323-0786

ISSN 2509-9264

(C) 2021. The Author(s).

This is an open access article published by Thieme under the terms of the Creative Commons Attribution-NonDerivative-NonCommercial-License, permitting copying and reproduction so long as the original work is given appropriate credit. Contents may not be used for commercial purposes, or adapted, remixed, transformed or built upon. (https://creativecommons.org/ licenses/by-nc-nd/4.0/)

Georg Thieme Verlag KG, Rüdigerstraße 14,

70469 Stuttgart, Germany

\section{Correspondence}

Dr. Kelly Oriakhi

Department of Medical Biochemistry

School of Basic Medical Sciences

University of Benin

PMB 1154, Ugbowo Campus

Benin City

Nigeria

Tel.: + 2347032979016,

Kelly.oriakhi@uniben.edu Supplementary Material is available under http://doi.
org/10.1055/a-1323-0786

\begin{abstract}
The present study was designed to evaluate the hypolipidemic activity of Tetracarpidium conophorum oil and its mechanism(s) of action. The oil was extracted using the Soxhlet method and subjected to column chromatography/spectroscopic techniques. GC-MS analysis was performed on the oil to identify 15 constituents with 9,12,15-octadecatrienoic acid ( $\omega$-3 fatty acid or $\alpha$-linolenic acid) (68\%) showing the highest proportion. Isolation and purification of the oil gave three compounds, namely, $\beta$-sitosterol, stigmasterol, and stearic acid (octadecanoic acid). Thirty-five rats were used and divided into seven groups for the in vivo hypolipidemic study. Findings from this study showed significant decreases $(p<0.05)$ in total cholesterol, triglycerides, and low-density lipoprotein cholesterol, and an increase in high-density lipoprotein cholesterol in rats fed a normal diet and receiving T. conophorum oil ( 250 and $500 \mathrm{mg} /$ $\mathrm{kg}$ body weight) for 20 days. But there were significant increases $(p<0.05)$ in total cholesterol, triglycerides, low-density lipoprotein cholesterol, creatine kinase, lactate dehydrogenase, aspartate amino transferase, malondialdehyde, 3-hydroxy3-methylglutaryl-coenzyme A reductase, and C-reactive protein levels with a decline in the low-density lipoprotein cholesterol level in rats fed the high cholesterol diet when compared to those fed a normal diet. However, oral administration of $T$. conophorum oil and atorvastatin for 20 days resulted in a significant lowering $(p<0.05)$ of triglycerides, low-density lipoprotein cholesterol, creatine kinase, lactate dehydrogenase, aspartate amino transferase, malondialdehyde, 3-hydroxy3-methylglutaryl-coenzyme A reductase, and C-reactive protein levels with a rise in high-density lipoprotein cholesterol in rats nourished with the high cholesterol diet. The study showed that $T$. conophorum seed oil possesses hypolipidemic and cardioprotective properties.
\end{abstract}




$\begin{array}{ll}\text { ABBREVIATIONS } \\ \text { AST } & \begin{array}{l}\text { aspartate amino transferase } \\ \text { atherogenic index }\end{array} \\ \mathrm{AI} & \begin{array}{l}\text { deuterated chloroform } \\ \mathrm{CDCl}_{3}\end{array} \\ \mathrm{CK} & \text { creatine kinase } \\ \text { CRI } & \text { coronary risk index } \\ \text { CRP } & \text { C-reactive protein } \\ \text { EI-MS } & \text { electron ionization-mass spectrometry } \\ \text { HCD } & \text { high-cholesterol diet } \\ \text { HDL-C } & \text { high-density lipoprotein cholesterol } \\ \text { HMG-CoA } & \text { 3-hydroxy-3-methylglutaryl-coenzyme A } \\ \text { LDH } & \text { lactate dehydrogenase } \\ \text { LDL-C } & \text { low-density lipoprotein cholesterol } \\ \text { MDA } & \text { malondialdehyde } \\ \text { ND } & \text { normal diet } \\ \text { TC } & \text { total cholesterol } \\ \text { TCO } & \text { Tetracarpidium conophorum oil } \\ \text { TC } & \text { triglyceride } \\ \text { TMS } & \text { tetramethylsilane } \\ & \end{array}$

\section{Introduction}

Hyperlipidemia is a disorder of fat metabolism and is ranked the fifth cause of death in the world [1]. This is widely caused by an increase in the consumption of high-calorie foods, lack of exercise, and sedentary lifestyle [2]. However, an increased concentration of serum cholesterol correlates with the rate of atherosclerosis and coronary heart disease [3]. Therefore, to prevent and treat this disease, blood lipid levels must be regulated.

Presently, some hypolipidemic drugs have been known for the treatment of hyperlipidemia. One of the most widely used hypolipidemic drugs currently is atorvastatin, which stops the ability of the hepatocytes to synthesize cholesterol by inhibiting the enzyme HMG-CoA reductase. This converts mevalonic acid to cholesterol [4]. Cholesterol and its metabolites silence the transcription of HMG-CoA reductase by stimulating the sterol-regulating elementbinding protein transcription factor. However, prolonged use of this drug brings about abhorrent side effects such as muscle weakness, myalgia, cramps, and aching that occur without an elevation of CK [5]. Such inimical effects of the conventional hypolipidemic drugs innervate the search for herbal medicine with improved efficacy and safety.

It is not uncommon that diet plays an essential role in reducing serum cholesterol. This is because diets rich in polyunsaturated and monosaturated fatty acids have been revealed to lower cholesterol [6]. Medicinal plants have always been abundant sources of biologically active compounds crucial to human health. Thus, the search for novel molecules with hypolipidemic properties from plants could be a useful approach in fighting this disease. One of such plant is Tetracarpidium conophorum, which is part of the Euphorbiaceae family [7]. It is commonly known in Southern Nigeria as ukpa (Igbo), in Western Nigeria as awusa or asala (Yoruba), and okhue in Bini [8]. An ethnobotanical survey of African walnut by ethno practitioners reported that the plant is used for the treat- ment of diabetes, hepatitis, lowering of blood pressure, heart-related problems, and weight reduction $[9,10]$, and has been validated by scientific reports on hepatoprotective [11], antioxidant [12], anti-infertility, antimicrobial [13,14], and antitumor activities [15] of African walnut. It is based on this background that this study sought to evaluate the hypolipidemic effect of TCO and its mechanism of action in rats fed an HCD.

\section{Results and Discussion}

Hypercholesterolemia is the cause of atherosclerotic vascular disease, heart attack, stroke, and peripheral vascular disease, which represent the most frequent cause of death in the world today [16]. Consumption of a high-cholesterol diet may lead to cardiovascular events and metabolic diseases such as diabetes and obesity [17]. Thus, regulating the abnormalities brought by high cholesterol concentrations in the blood is vital in the management of cardiovascular diseases. In the present study, TCO obtained from walnut seeds was subjected to GC-MS profiling, which revealed the presence of 15 constituents. The concentration of 9,12,15-octadecatrienoic acid ( $\alpha$-linolenic acid) was observed to be the highest, followed by Octadecanoic acid (stearic acid) of the seed oil ( $\triangleright$ Table 1 and Figs. 1S and 2S, Supporting Information). Consequently, three compounds from the $n$-hexane extract (TCO) of $T$. conophorum seeds were purified and their structures elucidated by spectroscopic methods (NMR analysis). The compounds isolated were $\beta$-sitosterol (1), stigmasterol (2), and stearic acid (octadecanoic acid) (3) (• Fig. 1 and Fig. 3S, Supporting Information). These compounds have been found to have a beneficial effect on heart-related diseases. Based on these findings, we went further to carry out in vivo experimental studies using a hypercholesterolemic rat model. However, to determine the dose of TCO in the in vivo study, acute toxicity of the oil was evaluated in Wistar rats. Findings from that study showed no physical sign of toxicity or mortality in groups that were administered $10-1000 \mathrm{mg} \mathrm{kg}^{-1}$ body weight within $24 \mathrm{~h}$ (first phase). In the second phase, rats that received 1600,2900 , and $5000 \mathrm{mg} \mathrm{kg}^{-1}$ body weight portrayed initial signs of hyperactivity but appeared calm afterwards. No mortality was recorded in these groups during the 24 -h observation period and 2 weeks afterward. The median lethal dose $\left(\mathrm{LD}_{50}\right)$ of TCO was determined to be $\geq 5000 \mathrm{mg} / \mathrm{kg}$ body weight (data in press).

The effect of TCO on the weight of rats fed an ND and HCD is shown in $>$ Table 2. There were significant differences in the weight gain pattern of the animals fed an HCD compared to those fed an ND. Rats fed an ND maintained a consistent weight gain at the end of the experimental period. Treatment of rats fed HCD with TCO (250 and $500 \mathrm{mg} / \mathrm{kg}$, body weight) and atorvastatin $(80 \mathrm{mg} / \mathrm{kg}$ ) caused significant reductions $(p<0.05)$ of body weight during the treatment periods. This finding agrees with the results of Fukuda and Yoshida [18], who found that walnut oil greatly reduced the body weight of mice fed a high-fat diet.

Furthermore, the results show that there were significant increases $(p<0.05)$ in TC, TG, and LDL-C levels in a dose-dependent manner with a reduction in HDL-C in rats induced by an HCD after 37 days (group II) when compared to the initial values at day 0 of the same rats and rats in the control group. Oral administration of TCO and atorvastatin given to the treatment groups for 20 days re- 
\Table 1 Compounds identified from TCO.

\begin{tabular}{|c|c|c|c|c|c|}
\hline Name of compound & Formula & MW & RT (Min) & Area \% & $\begin{array}{l}\text { Nature of } \\
\text { compound }\end{array}$ \\
\hline Hexadecanoic acid methyl ester & $\mathrm{C}_{17} \mathrm{H}_{34} \mathrm{O}_{2}$ & 270.0 & 21.38 & 3.31 & Fatty acid \\
\hline 7,10,13-Hexadecatrienoic acid, methyl ester & & 264.4 & 22.60 & & Fatty acid \\
\hline n-Hexadecanoic acid & $\mathrm{C}_{6} \mathrm{H}_{32} \mathrm{O}_{2}$ & 256.0 & 26.56 & 3.31 & Fatty acid \\
\hline 9,12,15-Octadecatrienoic acid & $\mathrm{C}_{18} \mathrm{H}_{30} \mathrm{O}_{2}$ & 278.4 & 28.40 & 68.45 & Fatty acid \\
\hline Octadecanoic acid, methyl ester & $\mathrm{C}_{19} \mathrm{H}_{38} \mathrm{O}_{2}$ & 298.0 & 25.02 & & Fatty acid \\
\hline 9,12-Octadecadienoic acid, methyl ester & $\mathrm{C}_{19} \mathrm{H}_{34} \mathrm{O}_{2}$ & 294.0 & 24.60 & & Fatty acid \\
\hline 9,12,15-Octadecatrienoic acid, methy ester & $\mathrm{C}_{19} \mathrm{H}_{32} \mathrm{O}_{2}$ & 292.0 & 24.57 & & Fatty acid \\
\hline 9,12,15-Octadecatrien-1-ol & $\mathrm{C}_{18} \mathrm{H}_{32} \mathrm{O}$ & 264.5 & 24.80 & & Fatty acid \\
\hline Octadecanoic acid & $\mathrm{C}_{18} \mathrm{H}_{36} \mathrm{O}_{2}$ & 284.0 & 26.37 & 7.51 & Fatty acid \\
\hline 9,12-Octadecadienoic acid & $\mathrm{C}_{18} \mathrm{H}_{32} \mathrm{O}_{2}$ & 280.0 & 25.32 & & Fatty acid \\
\hline 9,12-Octadecadienoyl Chloride & $\mathrm{C}_{18} \mathrm{H}_{31} \mathrm{ClO}$ & 298.0 & 28.88 & & Fatty acid \\
\hline 9,12,15-Octadecatrienoic acid, 2,3 dihydroxypropylester & $\mathrm{C}_{21} \mathrm{H}_{38} \mathrm{O}_{4}$ & 352.0 & 30.78 & & Fatty acid \\
\hline 1-Heptatriacotanol & $\mathrm{C}_{37} \mathrm{H}_{76} \mathrm{O}$ & 534.0 & 29.56 & & \\
\hline Butyl 9,12,15-octadecatrienoate & $\mathrm{C}_{22} \mathrm{H}_{38} \mathrm{O}_{2}$ & 334.0 & 28.90 & & \\
\hline Tricyclotriacontane1(22),7(16)-diepoxy & $\mathrm{C}_{30} \mathrm{H}_{52} \mathrm{O}_{2}$ & 444.0 & 45.95 & & \\
\hline 2-Pyridinecarboxylic acid, 5-butyl & $\mathrm{C}_{10} \mathrm{H}_{13} \mathrm{O}_{2}$ & 179.2 & 23.03 & 1.18 & \\
\hline
\end{tabular}

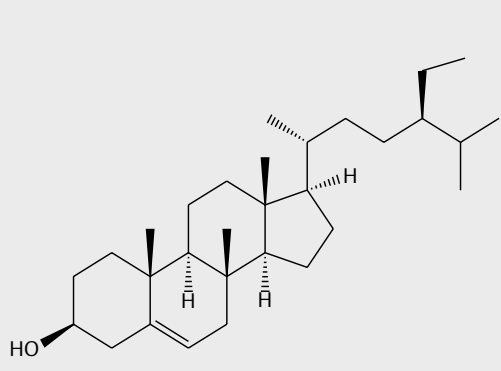

1

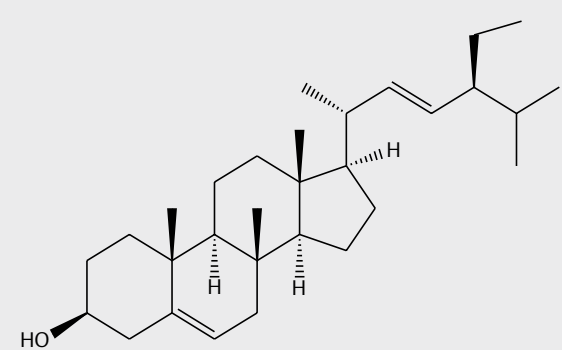

2

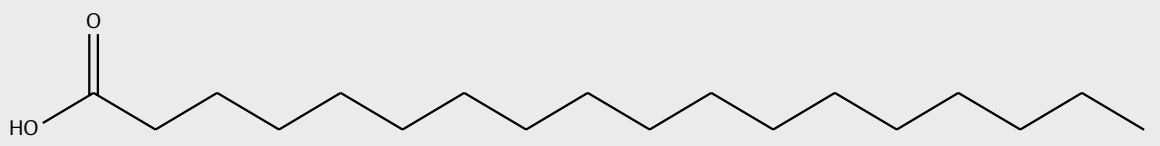

3

Fig. 1 Structure of compounds isolated from an $n$-hexane extract of $T$. conophorum seed: (1) $\beta$-sitosterol, (2) stigmasterol, (3) octadecanoic acid.

sulted in a significant lowering $(p<0.05)$ of TC, TG, and LDL-C levels with an increase in HDL-C in rats induced by an HCD. Nonetheless, there were also significant decreases $(p<0.05)$ in TC, TG, and LDL-C levels with an increase in HDL-C in rats administered 250 and $500 \mathrm{mg} / \mathrm{kg}$ body weight of TCO for 20 days and fed an ND when compared to the control ( $\triangleright$ Tables 3 and $\$ 4$ ). These findings are in agreement with Xia et al. [19] that a high-fat diet reduced the serum HDL-C level and elevated LDL-C, TG, and TC levels in the HFD group when compared to the control. This was also consistent with the study from Sibbett [20] that a diet containing walnuts lowers TC as well as LDL-C. It was demonstrated that a daily intake of $28 \mathrm{~g}$ of walnut can decrease serum levels of cholesterol and LDL-C by 4 and $6 \%$ respectively.

Consequently, just like the standard hypolipidemic drug atorvastatin, walnut oil has strong hypotriglyceridemic and hypocholesterolemic effects. However, walnut oil is not only therapeutic but 
safe for consumption, unlike the toxicities of atorvastatin, which include myalgia, cramps, and aching [5].

HDLs prevent the deposition of cholesterol on the arterial walls, thereby protecting the body from atherosclerosis and related incidences. This occurs as it carries cholesterol from extrahepatic tissues to the liver in reverse cholesterol transport. The walnut oil may activate the class B scavenger receptor B1 (HDL receptor) where it mediates cholesterol efflux from the cells by HDLs, which then transport it to the liver for excretion as bile acids in a process known as reverse cholesterol transport [21].

On the other hand, the high plasma concentration of LDL-C is associated with an increased risk of atherosclerosis and coronary heart disease [22]. LDL-C enters the subendothelial space of vessels and accumulates to bring about endothelial alterations and in-

- Table 2 Effect of T. conophorum seed oil on body weight of normal and hypercholesterolemic rats.

\begin{tabular}{|c|c|c|c|}
\hline \multirow[t]{2}{*}{ Groups } & \multicolumn{3}{|c|}{ Body weight (g) } \\
\hline & Initial weight & Final weight & $\begin{array}{l}\text { Weight } \\
\text { gained } \\
\text { (percentage } \\
\text { increase [\%]) }\end{array}$ \\
\hline Control & $132.90 \pm 0.89^{a}$ & $185.01 \pm 1.50^{\mathrm{b}}$ & 28.17 \\
\hline HCD & $129.89 \pm 0.51^{a}$ & $220.00 \pm 5.50^{b}$ & 41.36 \\
\hline $\mathrm{ND}+250 \mathrm{mg} / \mathrm{kg}$ & $131.50 \pm 0.02^{\mathrm{a}}$ & $164.00 \pm 0.13^{b^{*}}$ & 19.81 \\
\hline $\mathrm{ND}+500 \mathrm{mg} / \mathrm{kg}$ & $130.40 \pm 0.11^{\mathrm{a}}$ & $160.00 \pm 0.42^{b^{*}}$ & 18.50 \\
\hline $\mathrm{HCD}+250 \mathrm{mg} / \mathrm{kg}$ & $122.32 \pm 0.02^{\mathrm{a}}$ & $132.40 \pm 0.55^{* *}$ & 7.60 \\
\hline $\mathrm{HCD}+500 \mathrm{mg} / \mathrm{kg}$ & $118.27 \pm 1.70^{\mathrm{a}}$ & $128.97 \pm 0.25^{* *}$ & 8.30 \\
\hline $\begin{array}{l}\mathrm{HCD}+80 \mathrm{mg} / \mathrm{kg} \\
\text { Atorvastatin }\end{array}$ & $117.68 \pm 1.71^{\mathrm{a}}$ & $130.62 \pm 0.25^{* *}$ & 9.90 \\
\hline \multicolumn{4}{|c|}{$\begin{array}{l}\text { Values are expressed as the mean } \pm S D, n=5 / \text { group. Different lowercase } \\
\text { letters represent a significant difference between means at } p<0.05 \text {. "The } \\
\text { mean is significant }(p<0.05) \text { when compared with the control. }{ }^{* *} \text { The } \\
\text { mean is significant }(p<0.05) \text { when compared with an } H C D \text {. }\end{array}$} \\
\hline
\end{tabular}

flammatory responses, thereby creating atherogenic lesions along the inner walls of the arteries [23]. Sudden obstruction of coronary arteries results in a myocardial infarction or heart attack. Under such conditions, plasma levels of LDH and CK rise significantly, due to damage of heart muscles ( $\triangleright$ Table 5 ).

An $\mathrm{Al}$ is the ratio of LDL-C to HDL-C, while CRI is the ratio of TC to $\mathrm{HDL}-\mathrm{C}$. They are strong markers to predict the risk of atherosclerosis and coronary heart diseases. Results from this study showed that there were significant increases in Al and CRI in rats fed an HCD compared to rats fed an ND. Treatment of the hypercholesteromic rats with 250 and $500 \mathrm{mg} / \mathrm{kg}$ of walnut oil and $80 \mathrm{mg} / \mathrm{kg}$ of atorvastatin for 20 days decreases $\mathrm{Al}$ and CRI in a dose-dependent manner ( $\triangleright$ Table 6). A significant reduction of Al and CRI was also reported by Chaudhari et al. [23] using embelin extracted from Embelia ribes. On the contrary, LDL/HDL and TC/HDL ratios are better markers than LDL-C and HDL-C levels [24, 25]. A significant reduction in Al and CRI after treatment with walnut oil is evident in the elevation of the plasma level of HDL-C. The rise in HDL-C concentration in the plasma may suggest that walnut oil possesses some health benefits and serves as a good agent in reducing high plasma lipid profiles [26]. Another possible mechanism of action that could lower the synthesis of cholesterol in the liver is the use of statin drugs. These drugs have proven to be highly efficacious in reducing plasma cholesterol and preventing heart disease. Statins act by inhibiting HMG-CoA reductase and upregulating LDL receptor activity [27]. The activities of HMG-CoA reductase were evaluated in the liver and it was observed in rats fed an HCD alone. Throughout the experiment, HMGCoA reductase activity significantly increased $(p<0.05)$ compared to control rats fed an ND. However, there was a dose-dependent decrease in HMG-CoA reductase activity when treated with walnut oil ( $\triangleright$ Fig. 2). The walnut oil, rich in $\omega$-3 fatty acid and plant sterols ( $\beta$ sitosterol and stigmasterol), may have acted like statin by inhibiting HMG-CoA reductase. A lipid-rich diet results in increased lipid peroxidation and inflammation. The primary products of lipid peroxida-

- Table 3 Effect of walnut oil on TC and TG in rats fed an HCD and ND.

\begin{tabular}{|c|c|c|c|c|c|}
\hline $\begin{array}{l}\text { Biochemical } \\
\text { parameters }\end{array}$ & Treatment group & Day 0 & Day 37 & Day 53 & Day 58 \\
\hline \multirow[t]{7}{*}{ TC } & Control & $89.50 \pm 2.12$ & $87.20 \pm 3.10$ & $84.21 \pm 2.20$ & $86.15 \pm 1.61$ \\
\hline & HCD & $70.81 \pm 1.50$ & $216.21 \pm 5.12^{\mathrm{a}}$ & $205.35 \pm 4.41^{\mathrm{a}}$ & $207.20 \pm 2.11^{\mathrm{a}}$ \\
\hline & $\mathrm{ND}+250 \mathrm{mg} / \mathrm{kg}$ & $84.05 \pm 2.40$ & $80.12 \pm 1.50$ & $68.67 \pm 0.55^{*}$ & $65.00 \pm 2.30^{*}$ \\
\hline & $\mathrm{ND}+500 \mathrm{mg} / \mathrm{kg}$ & $86.98 \pm 1.50$ & $77.25 \pm 0.50^{*}$ & $63.50 \pm .50^{*}$ & $62.81 \pm 2.40^{*}$ \\
\hline & $\mathrm{HCD}+250 \mathrm{mg} / \mathrm{kg}$ & $60.81 \pm 2.51$ & $180.33 \pm 6.10^{* *}$ & $108.90 \pm 3.20^{* *}$ & $82.40 \pm 2.60^{*}$ \\
\hline & $\mathrm{HCD}+500 \mathrm{mg} / \mathrm{kg}$ & $72.84 \pm 1.15$ & $204.49 \pm 2.10^{* *}$ & $91.55 \pm 3.10^{* *}$ & $92.05 \pm 3.22^{*}$ \\
\hline & $\mathrm{HCD}+80 \mathrm{mg} / \mathrm{kg}$ Atorvastatin & $83.91 \pm 2.50$ & $201.92 \pm 4.31^{* *}$ & $98.75 \pm 2.60^{* *}$ & $95.40 \pm 4.45^{*}$ \\
\hline \multirow[t]{7}{*}{ TG } & Control & $87.91 \pm 2.00$ & $81.20 \pm 2.15$ & $72.42 \pm 1.80$ & $77.00 \pm 1.50$ \\
\hline & HCD & $76.51 \pm 1.61$ & $120.71 \pm 6.24^{\mathrm{a}}$ & $124.81 \pm 3.51^{\mathrm{a}}$ & $130.12 \pm 2.50^{\mathrm{a}}$ \\
\hline & $\mathrm{ND}+250 \mathrm{mg} / \mathrm{kg}$ & $88.40 \pm 3.20$ & $86.87 \pm 1.80$ & $80.40 \pm 1.50^{*}$ & $81.58 \pm 2.41^{*}$ \\
\hline & $\mathrm{ND}+500 \mathrm{mg} / \mathrm{kg}$ & $89.34 \pm 2.50$ & $90.20 \pm 1.50$ & $100.00 \pm 3.00^{*}$ & $96.26 \pm 1.71^{*}$ \\
\hline & $\mathrm{HCD}+250 \mathrm{mg} / \mathrm{kg}$ & $35.59 \pm 1.50$ & $114.52 \pm 3.25^{* *}$ & $70.81 \pm 1.59^{* *}$ & $65.87 \pm 2.51^{*}$ \\
\hline & $\mathrm{HCD}+500 \mathrm{mg} / \mathrm{kg}$ & $43.98 \pm 0.99$ & $100.12 \pm 1.82^{* *}$ & $72.23 \pm 1.55^{* *}$ & $52.30 \pm 0.14^{*}$ \\
\hline & HCD $+80 \mathrm{mg} / \mathrm{kg}$ Atorvastatin & $31.05 \pm 0.55$ & $118.65 \pm 4.90^{* *}$ & $45.02 \pm 1.37^{* *}$ & $25.68 \pm 1.20^{* \prime}$ \\
\hline
\end{tabular}


- Table 4 Effect of walnut oil on serum lipoproteins in rats fed an HCD and ND.

\begin{tabular}{|c|c|c|c|c|c|}
\hline $\begin{array}{l}\text { Biochemical } \\
\text { parameters }\end{array}$ & Treatment group & Day 0 & Day 37 & Day 53 & Day 58 \\
\hline \multirow[t]{7}{*}{ HDL-C } & Control & $47.20 \pm 2.62$ & $46.10 \pm 3.17$ & $51.25 \pm 0.64$ & $48.50 \pm 0.50$ \\
\hline & HCD & $47.71 \pm 2.70$ & $21.03 \pm 1.50^{\mathrm{a}}$ & $18.20 \pm 0.35^{\mathrm{a}}$ & $18.58 \pm 0.25^{\mathrm{a}}$ \\
\hline & $\mathrm{ND}+250 \mathrm{mg} / \mathrm{kg}$ & $45.81 \pm 1.27$ & $48.61 \pm 1.25$ & $49.62 \pm 0.48$ & $50.21 \pm 0.55$ \\
\hline & $\mathrm{ND}+500 \mathrm{mg} / \mathrm{kg}$ & $42.13 \pm 1.00$ & $42.94 \pm 0.56^{*}$ & $41.80 \pm 0.50^{*}$ & $42.77 \pm 0.87^{*}$ \\
\hline & $\mathrm{HCD}+250 \mathrm{mg} / \mathrm{kg}$ & $41.13 \pm 2.00$ & $29.59 \pm 0.25^{* *}$ & $41.62 \pm 0.59^{* *}$ & $41.10 \pm 0.45$ \\
\hline & $\mathrm{HCD}+500 \mathrm{mg} / \mathrm{kg}$ & $43.93 \pm 1.50$ & $30.90 \pm 0.50^{* *}$ & $41.57 \pm 0.92^{* *}$ & $42.37 \pm 0.51^{* *}$ \\
\hline & $\mathrm{HCD}+80 \mathrm{mg} / \mathrm{kg}$ atorvastatin & $41.99 \pm 2.50$ & $25.05 \pm 0.91^{* *}$ & $39.89 \pm 0.40^{* *}$ & $39.90 \pm 0.30^{* *}$ \\
\hline \multirow[t]{7}{*}{ LDL-C } & Control & $24.72 \pm 1.50$ & $24.36 \pm 1.15$ & $16.48 \pm 2.51$ & $22.25 \pm 1.50$ \\
\hline & HCD & $17.80 \pm 1.50$ & $171.04 \pm 6.24^{\mathrm{a}}$ & $162.14 \pm 5.80^{\mathrm{a}}$ & $162.62 \pm 7.80^{\mathrm{a}}$ \\
\hline & $\mathrm{ND}+250 \mathrm{mg} / \mathrm{kg}$ & $20.56 \pm 1.20$ & $10.36 \pm 1.50^{*}$ & $2.97 \pm 0.09^{*}$ & $1.53 \pm 0.01^{*}$ \\
\hline & $\mathrm{ND}+500 \mathrm{mg} / \mathrm{kg}$ & $26.98 \pm 0.50$ & $12.06 \pm 0.56^{*}$ & $1.70 \pm 0.10^{*}$ & $0.85 \pm 0.03^{*}$ \\
\hline & $\mathrm{HCD}+250 \mathrm{mg} / \mathrm{kg}$ & $12.56 \pm 1.50$ & $87.84 \pm 3.25^{* *}$ & $53.12 \pm 2.50^{* *}$ & $28.13 \pm 1.52^{* *}$ \\
\hline & $\mathrm{HCD}+500 \mathrm{mg} / \mathrm{kg}$ & $20.12 \pm 0.78$ & $153.57 \pm 4.82^{* *}$ & $35.53 \pm 1.50^{* *}$ & $39.20 \pm 1.70^{* *}$ \\
\hline & $\mathrm{HCD}+80 \mathrm{mg} / \mathrm{kg}$ atorvastatin & $35.71 \pm 3.55$ & $153.14 \pm 4.91^{* *}$ & $49.86 \pm 1.34^{* *}$ & $50.36 \pm 2.40^{* *}$ \\
\hline
\end{tabular}

- Table 5 Effect of T. conophorum seed oil on some biochemical parameters.

\begin{tabular}{|c|c|c|c|}
\hline Treatment & CK (U/L) & LDH (U/L) & AST (U/L) \\
\hline Control & $19.89 \pm 0.35$ & $25.50 \pm 1.50$ & $131.93 \pm 0.52$ \\
\hline HCD & $28.28 \pm 0.03^{a}$ & $32.50 \pm 2.20^{\mathrm{a}}$ & $132.80 \pm 0.92$ \\
\hline $\mathrm{ND}+250 \mathrm{mg} / \mathrm{kg}$ bw & $13.09 \pm 0.45^{*}$ & $25.10 \pm 0.55$ & $133.86 \pm 1.72$ \\
\hline $\mathrm{ND}+500 \mathrm{mg} / \mathrm{kg}$ bw & $12.16 \pm 0.02^{*}$ & $20.10 \pm 0.25^{*}$ & $135.25 \pm 1.21^{*}$ \\
\hline $\mathrm{HCD}+250 \mathrm{mg} / \mathrm{kg}$ bw & $21.59 \pm 0.01^{* *}$ & $30.00 \pm 2.00^{* *}$ & $135.94 \pm 0.69^{* *}$ \\
\hline $\mathrm{HCD}+500 \mathrm{mg} / \mathrm{kg}$ bw & $15.98 \pm 0.38^{* *}$ & $22.00 \pm 1.55^{* *}$ & $134.42 \pm 0.92^{* *}$ \\
\hline $\mathrm{HCD}+$ atorvastatin $(80 \mathrm{mg} / \mathrm{kg} \mathrm{bw})$ & $11.76 \pm 0.30^{* *}$ & $10.20 \pm 1.40^{* *}$ & $136.03 \pm 3.09^{* *}$ \\
\hline
\end{tabular}

- Table 6 Effect of walnut oil on Al and CRI in rats fed an HCD and ND.

\begin{tabular}{|c|c|c|c|c|c|}
\hline $\begin{array}{l}\text { Biochemical } \\
\text { parameters }\end{array}$ & Treatment group & Day 0 & Day 37 & Day 53 & Day 58 \\
\hline \multirow{7}{*}{$\begin{array}{l}\text { Atherogenic } \\
\text { index (LDL/HDL) }\end{array}$} & Control & $0.53 \pm 0.02$ & $0.53 \pm 0.02$ & $0.32 \pm 0.01$ & $0.45 \pm 0.03$ \\
\hline & HCD & $0.16 \pm 0.01$ & $8.13 \pm 1.20^{\mathrm{a}}$ & $8.19 \pm 1.15^{\mathrm{a}}$ & $8.75 \pm 0.85^{a}$ \\
\hline & $\mathrm{ND}+250 \mathrm{mg} / \mathrm{kg}$ & $0.45 \pm 0.05$ & $0.32 \pm 0.02^{*}$ & $0.060 \pm 0.001^{*}$ & $0.030 \pm 0.001^{*}$ \\
\hline & $\mathrm{ND}+500 \mathrm{mg} / \mathrm{kg}$ & $0.64 \pm 0.01$ & $0.28 \pm 0.02^{*}$ & $0.040 \pm 0.002^{*}$ & $0.020 \pm 0.001^{*}$ \\
\hline & $\mathrm{HCD}+250 \mathrm{mg} / \mathrm{kg}$ & $0.31 \pm 0.01$ & $2.97 \pm 0.25^{* *}$ & $1.28 \pm 0.12^{* *}$ & $6.68 \pm 0.06$ \\
\hline & $\mathrm{HCD}+500 \mathrm{mg} / \mathrm{kg}$ & $0.46 \pm 0.03$ & $4.92 \pm 0.35^{* *}$ & $0.85 \pm 0.03^{* *}$ & $0.93 \pm 0.03^{* *}$ \\
\hline & $\mathrm{HCD}+80 \mathrm{mg} / \mathrm{kg}$ Atorvastatin & $0.85 \pm 0.02$ & $6.11 \pm 0.50^{* *}$ & $1.25 \pm 0.05^{* *}$ & $1.26 \pm 0.03^{* *}$ \\
\hline \multirow{7}{*}{$\begin{array}{l}\text { Coronary risk } \\
\text { index (CRI) }\end{array}$} & Control & $1.89 \pm 0.02$ & $1.19 \pm 0.02$ & $1.64 \pm 0.12$ & $1.70 \pm 0.025$ \\
\hline & HCD & $1.48 \pm 0.06$ & $10.28 \pm 1.50^{\mathrm{a}}$ & $11.28 \pm 0.36^{\mathrm{a}}$ & $11.15 \pm 0.25^{a}$ \\
\hline & $\mathrm{ND}+250 \mathrm{mg} / \mathrm{kg}$ & $1.83 \pm 0.20$ & $1.59 \pm 0.11$ & $1.38 \pm 0.48^{*}$ & $1.29 \pm 0.08^{*}$ \\
\hline & $\mathrm{ND}+500 \mathrm{mg} / \mathrm{kg}$ & $2.06 \pm 0.56$ & $1.79 \pm 0.36$ & $1.52 \pm 0.15^{*}$ & $1.47 \pm 0.07^{*}$ \\
\hline & $\mathrm{HCD}+250 \mathrm{mg} / \mathrm{kg}$ & $1.48 \pm 0.12$ & $6.19 \pm 1.20^{* *}$ & $2.62 \pm 0.50^{* *}$ & $2.00 \pm 0.15^{* *}$ \\
\hline & $\mathrm{HCD}+500 \mathrm{mg} / \mathrm{kg}$ & $1.66 \pm 0.25$ & $6.62 \pm 1.50^{* *}$ & $2.19 \pm 9.92^{* *}$ & $2.17 \pm 0.15^{* *}$ \\
\hline & $\mathrm{HCD}+80 \mathrm{mg} / \mathrm{kg}$ atorvastatin & $1.99 \pm 0.45$ & $8.07 \pm 0.60^{* *}$ & $2.48 \pm 0.40^{* *}$ & $2.39 \pm 0.30^{* *}$ \\
\hline
\end{tabular}


tion can undergo carbon-carbon bond cleavage to form MDA. Results from this study showed significant increases $(p<0.05)$ in MDA and CRP levels in rats fed an HCD (group II) when compared to control rats. Rats fed an HCD are prone to oxidative stress and inflammation, a condition that causes cellular damage and coronary vascular diseases [28, 29]. However, the administration of walnut oil significantly attenuated ( $p<0.05)$ MDA and CRP levels. Similarly, there were significant reductions in MDA and CRP levels in rats given atorvastatin (group VII) (>Figs. 3 and \$4). Therefore, findings from these results suggest that walnut oil is as effective as the standard drug atorvastatin in scavenging or mopping up free radicals and inhibiting lipid peroxidation, thus attenuating atherogenic processes. Walnut oil has been extensively reported for its antioxidant capacity [30], which is mainly dependent on phenolic compounds.

In conclusion, in this study, TCO has been shown to reduce or control the amount of serum cholesterol and may act like a statin by inhibiting HMG-CoA reductase. Walnut oil being a rich source of $\omega-3$ fatty acids could protect the heart from oxidative damage and inflammation.

\section{Materials and Methods}

\section{General experimental procedures}

The chemical composition of the oil was determined by a chromatographic-spectrometric technique (GC-MS) (Perkin-Elmer instrument). Proton NMR spectra were run on Bruker Avance AV-600 spectrometers. The samples were dissolved in $\mathrm{CDCl}_{3}$. TMS was used as referential $\left(\delta_{\mathrm{H}}=0\right)$ and coupling constants in $\mathrm{Hz}$. Mass spectrometry was carried out on an electron impact-mass spectrometer (EIMS) (JEOL MS 600H). Analytical precoated TLC silica gel 60 from Sigma-Aldrich was used for thin-layer chromatography and visualized under short ( $254 \mathrm{~nm}$ ) and long (366 nm) wavelength UV light. Column chromatography was conducted using Kieselgel $60 \mathrm{G}$ (silica gel 60-200 mesh; Merck). All solvents used were of analytical grade (Sigma-Aldrich). Atorvastatin was purchased from the United State Pharmacopoeia with a purity of $98 \%$.

\section{Plant materials}

Collection of plant materials

The seeds of $T$. conophorum used were collected from an open forest in Benin City, Nigeria. The fresh walnut seeds were identified and authenticated by Professor MacDonald Idu from the Department of Plant Biology and Biotechnology of the University of Benin, Benin City, Nigeria. A plant specimen (voucher number UBHe0153) was deposited at the Herbarium of the University of Benin.

\section{Extraction}

The extraction of $500 \mathrm{~g}$ of dried seed powder of $T$. conophorum was carried out in a Soxhlet extractor using $n$-hexane $(5 \times 1000 \mathrm{~mL})$ at $40-60{ }^{\circ} \mathrm{C}$ for $6 \mathrm{~h}$. The oil was obtained after the solvent had been removed under reduced temperature and pressure and refluxing at $70{ }^{\circ} \mathrm{C}$ to remove the excess solvent in the oil. The yield of the oil (TCO) was $3.5 \%$.

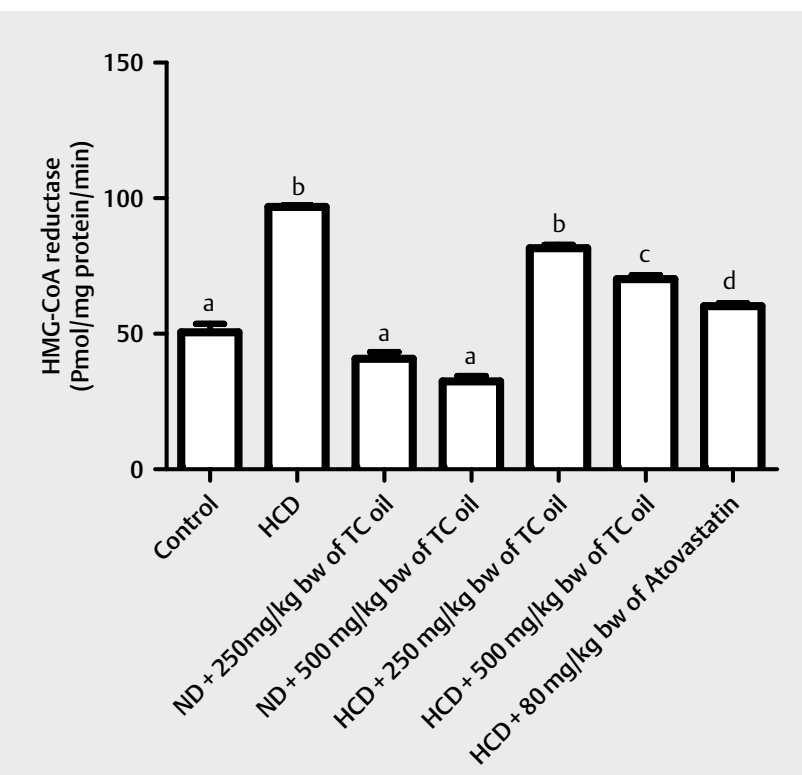

- Fig. 2 Effect of TCO (African walnut) on liver HMG-CoA reductase activity in rats fed an HCD and ND. Different lowercase letters represent a significant difference between means at $p<0.05$.

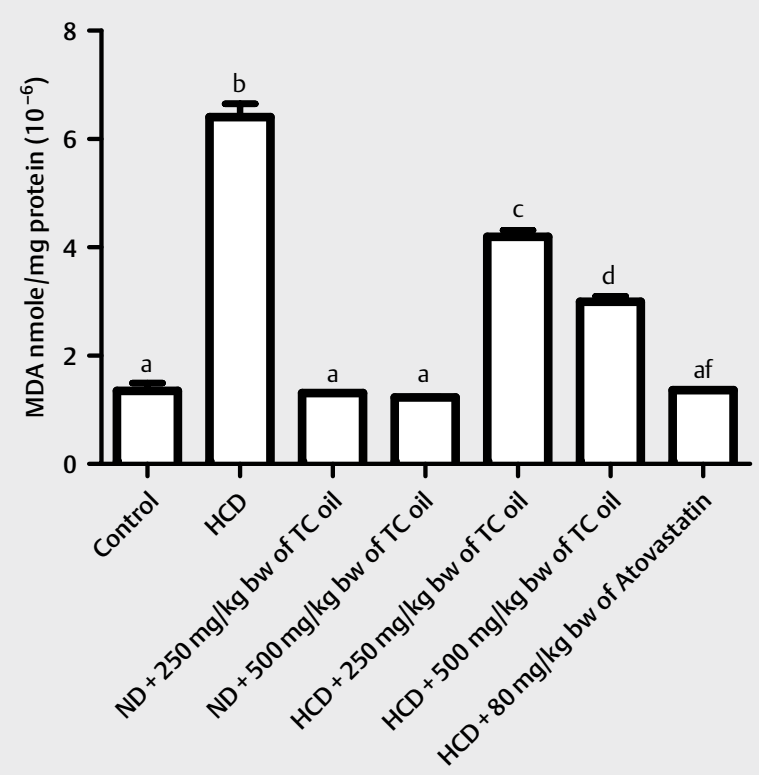

- Fig. 3 Effect of TCO (African walnut) on liver MDA levels in rats fed an HCD and ND. Different lowercase letters represent a significant difference between means at $p<0.05$.

\section{GC-MS analysis}

GC-MS analysis of the oil from T. conophorum seeds was performed according to the method described by Adams [31]. 


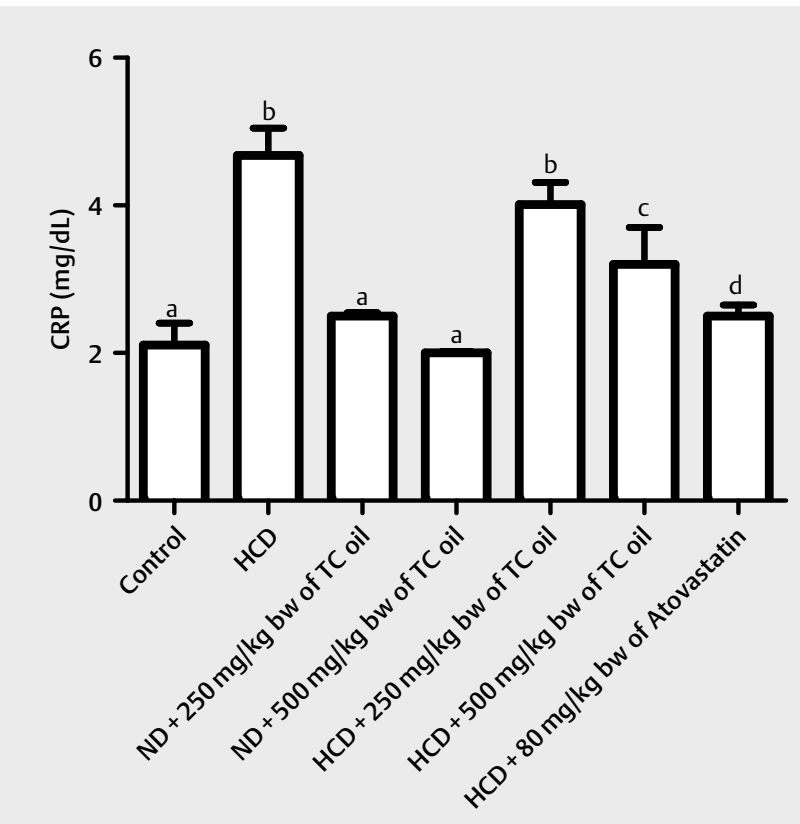

- Fig. 4 Effect of TCO (African walnut) on the serum CRP levels in rats fed an HCD and ND. Different lowercase letters represent a significant difference between means at $p<0.05$.

Isolation of compounds from Tetracarpidium conophorum seeds oil

The $n$-hexane extract $(3.2 \mathrm{~g} \mathrm{v} / \mathrm{w})$ was loaded on a column chromatography over Silical gel as a stationary phase. The column was eluted using solvent combinations of hexane-EtOAc, EtOAc-methanol in a stepwise gradient of increasing polarity to obtain 81 fractions. TLC analyses of the fractions were carried out using suitable solvent systems of hexane-EtOAc (9.5:0.5, 9:1, 4:1, 1:1) The plates were viewed under UV lamp at 254 and $366 \mathrm{~nm}$ and were later sprayed with ceric sulphate and then visualized by drying with hot air. The fractions with similar TLC profiles were combined to give 9 subfractions. Subfractions 1 and 2 afforded a mixture of fatty acids ( $300 \mathrm{mg}$ ). Subfractions 3,4 , and 5 were a complex mixture and were discarded, while subfraction 6 gave crystals of $\beta$-sitosterol (1) (200 mg). After further purification, subfraction 7 gave stigmasterol (2) (150 mg) and octadecanoic acid (stearic acid) (3) (50 mg). Frs. 8 and 9 afforded nothing of interest in a sufficient quantity.

\section{Animals}

Ten-week-old male albino rats (Wistar strain, 160-180 g), bred in the Department of Biochemistry, Faculty of Life Science, University of Benin, Benin City, Nigeria, were used for the study. They were kept in clean cages in a 12-h light/dark cycle with the litter changed daily. The animals were housed in galvanized rat cages and acclimatized for 2 weeks before the commencement of the experiment. They were fed with guinea growers mash and had access to water ad libitum.

\section{Animal ethics and guidelines}

The guide and care of animals followed the principles of laboratory animal care [32]. The institutional Ethical Review Committee of the
Faculty of Life Sciences, University of Benin, Nigeria, approved the use of the experimental rats on December 19, 2018 with approval number LS19109.

\section{Induction of hypercholesterolemia}

Thirty-five albino rats ( 5 per group) were used for this experiment. The normal and hypercholesterolemic diets were prepared according to Reeves et al. [33] (Table 1S, Supporting Information).

\section{Experimental design}

Group 1: Normal control (ND) rats were fed an ND for 57 days.

Group II: Hypercholesterolemic rats (positive control) were fed a hypercholesterolemic diet (HCD) for 37 days and ND for 20 days.

Group III: Rats were fed an ND for 37 days; thereafter, they were administered $250 \mathrm{mg} / \mathrm{kg}$ body weight of TCO orally for 20 days and fed an ND during this period.

Group IV: Rats were fed an ND for 37 days; thereafter, they were administered $500 \mathrm{mg} / \mathrm{kg}$ body weight of TCO for 20 days and fed an ND during this period.

Group V: Rats were fed a hypercholesterolemic diet for 37 days; thereafter, they were administered $250 \mathrm{mg} / \mathrm{kg}$ body weight of TCO orally for 20 days and fed an ND during this period.

Group VI: Rats were fed a hypercholesterolemic diet for 37 days; thereafter, they were administered $500 \mathrm{mg} / \mathrm{kg}$ body weight of TCO orally for 20 days and fed an ND during this period.

Group VII: Rats were fed a hypercholesterolemic diet for 37 days; thereafter, they were administered the hypocholesterolemic drug atorvastatin $(80 \mathrm{mg} / \mathrm{kg}$ body weight) orally for 20 days and fed an ND during this period.

A blood sample was collected from the rat's tail by gentle massaging into a plain tube on day 0 , day 37 , and day 53 to monitor blood lipids. At the end of 20 days (day 58) of administration of the oil, rats were fasted overnight, anesthetized with chloroform, and blood was withdrawn from the heart. The blood sample was collected in plain test tubes and centrifuged ( $4000 \mathrm{rpm}, 10 \mathrm{~min}$ ) to obtain serum. Serum TC and serum HDL-C levels were determined according to the method described by Allain and Lopes-Virella et al. [34, 35], respectively. The serum LDL-C level was determined according to the method described by Fruchart [36]. The serum TG level was determined according to the method described by Bucolo and David [37]. The LDH and CK were determined using Randox kits. Serum CRP was determined using a sandwich ELISA colorimetric protocol.

\section{Preparation of liver homogenate}

The livers from the rats were promptly excised and chilled in icecold saline. After washing with saline, they were blotted and weighed. Each liver was cut into pieces, and $10 \mathrm{~g}$ of wet tissue were homogenized with $90 \mathrm{~mL}$ of chilled $0.1 \mathrm{M}$ sodium phosphate buffer, $\mathrm{pH} 7.4$, containing $1.17 \% \mathrm{KCl}$ in a waring blender. The homogenate was centrifuged at $1000 \mathrm{rpm}$ for $10 \mathrm{~min}$ at $4^{\circ} \mathrm{C}$, and finally aliquoted and stored at $-20^{\circ} \mathrm{C}$. 


\section{3-Hydroxy-3-methylglutaryl-coenzyme A reductase activity}

HMG-CoA reductase enzyme activity in the liver homogenate was estimated indirectly as described by Rao and Ramakrishnan [38] with slight modifications. Fresh $10 \%$ tissue homogenate $(1 \mathrm{~mL})$ was mixed with $9 \mathrm{~mL}$ of saline arsenate $(0.1 \%$ sodium arsenate in physiological saline), and then $10 \mathrm{~mL}$ of $5 \%$ perchloric acid were added. It was incubated for $5 \mathrm{~min}$ at room temperature, followed by centrifugation at $2000 \mathrm{rpm}$ for $10 \mathrm{~min}$. One microliter of the supernatant from each tube was taken out and mixed with $0.5 \mathrm{~mL}$ of freshly prepared $1 \mathrm{M}$ aqueous hydroxylamine hydrochloride, whereas for the assay of HMG-CoA, $0.5 \mathrm{~mL}$ of alkaline hydroxylamine hydrochloride was added and mixed. After an incubation of $5 \mathrm{~min}$ at room temperature, $1.5 \mathrm{~mL}$ of $0.616 \mathrm{M}$ ferric chloride reagent containing $5.2 \%$ TCA, prepared in $0.65 \mathrm{~N} \mathrm{HCl}$, were added and mixed, and the absorbance was taken at $540 \mathrm{~nm}$ against a reagent blank using a Biospectrum kinetics spectrophotometer (Eppendorf) after 10 min of incubation at room temperature.

\section{Determination of lipid peroxidation (malondialdehyde levels)}

Lipid peroxidation (MDA) levels were determined as described by Varshney and Kale [39].

\section{Statistical analysis}

Data are expressed as the mean \pm SEM/SD using the statistical package for social science (SPSS) version 22.0 for Windows. Statistical significance was calculated by one-way analysis of variance by multiple comparisons. Differences between means were estimated by Duncan's multiple range tests.

Compound $\mathbf{1}$ was isolated as a solid white powder and its mass spectral data suggested the molecular formula as $\mathrm{C}_{29} \mathrm{H}_{50} \mathrm{O}$ with a molecular ion $\left(\mathrm{M}^{+}\right)$of $414 \mathrm{~m} / \mathrm{z}$. The ${ }^{1} \mathrm{H}$ NMR spectra of compound 1 showed the presence of six signals that appeared as two singlets at $\delta 0.68$ and 1.01 , three doublets that appeared at $\delta 0.81,0.83$, and 0.93 , and a triplet at $\delta 0.84$. Thus, the structure of compound 1 was assigned as $\beta$-sitosterol, which is consistent with the reported literature values [40].

Compound 2 was isolated as a white powder solid and its mass spectral data suggested the molecular formula as $\mathrm{C}_{29} \mathrm{H}_{48} \mathrm{O}$ with a molecular ion $\left(\mathrm{M}^{+}\right)$of $412 \mathrm{~m} / \mathrm{z} .{ }^{1} \mathrm{H}$ NMR spectra of compound 2 showed the presence of two singlets at $\delta 0.71$ and 1.03 , three doublets that appeared at $\delta 0.80,0.82$, and 0.91 , and a triplet at $\delta 0.83$. It showed protons at $\delta 4.98,5.14$, and 5.31 , suggesting the presence of a trisubstituted and a disubstituted olefinic bond. The proton corresponding to the $\mathrm{H}-3$ of a sterol moiety appeared as a triplet of a doublet of doublets at $\delta 3.51$. Thus, the structure of 2 was assigned as stigmasterol. The spectral data are consistent with the reported literature $[41,42]$.

Compound $\mathbf{3}$ was isolated as a white waxy solid with a molecular ion peak at $\mathrm{m} / \mathrm{z} 284$ corresponding to its $\mathrm{M}^{+}$ion, suggesting the molecular formula $\mathrm{C}_{18} \mathrm{H}_{36} \mathrm{O}_{2}$. The NMR spectrum showed typical signals for $\mathrm{CH}_{3}\left(\mathrm{CH}_{2}\right)$ n. It was identified as stearic acid (octadecanoic acid) by comparison with physical and spectral data from the literature [43].

\section{Supporting information}

Composition of experimental diets, ${ }^{1} \mathrm{H}$ NMR spectra of compounds $\mathbf{1 - 3}$, and the detailed procedure for the isolation of the compounds are available as Supporting Information.

\section{Funding}

The research was funded by the Tertiary Trust Fund, the University of Benin, Benin City, Nigeria to Oriakhi Kelly, Department of Medical Biochemistry, University of Benin, and the ICCBS-TWAS Postgraduate Fellowship award (FR No. 3240280482). The authors also strongly thank the Natural Product Research and Disease Control Laboratory (NPRDC), Department of Biochemistry, University of Benin for providing the facilities needed to carry out this study.

\section{Conflict of Interest}

The authors declare that they have no conflict of interest

\section{References}

[1] Thayyil AH, Surulivel MKM, Ahmed MF, Ahamed GSS, Sidheeq A, Rasheed A, Ibrahim M. Hypolipidemic activity of Luffa aegiptiaca fruits in cholesterol fed hypercholesterolemic rabbits. Int J Pharm Appl 2011; 2: 81-88

[2] Jacobson TA, Miller M, Schaefer E]. Hypertriglyceridemia and cardiovascular risk reduction. Clin Ther 2007; 29: 763-777

[3] Shayganni E, Bahmani M, Asgary S, Rafieian-Kopael M. Inflammaging and cardiovascular disease: Management by medicinal plants. Phytomedicine 2016; 23: 1119-1120

[4] Stancu C, Sima S. Statins: mechanism of action and effects. J Cell Mol Med 2001; 5: 378-387

[5] Thompson PD, Panza G, Zaleski A, Taylor B. Statin-Associated Side Effects. J Am Coll Cardiol 2016; 67: 2395-2410

[6] Hutchinson J, Dalziel JM. Tropical African plants: III. Bulletin of miscellaneous information / Royal Botanic Gardens, Kew 1928; 211-229

[7] Oyekale KO, Odutayo OI, Esan EB, Ogunwemimo KO, Denton OA, Bolaji DT. Comparative studies on phytochemical and proximate composition of four morphological distinct segment of the conophor seedlings (Tetracarpidum conopphorum Hutch and Dalziel). Brazilian J Biol Sci 2015; 3: 91-100

[8] Oke OL. Leaf Protein Research in Nigeria Ibadan. Oyo University of Ibadan Press; 1995

[9] Ezealisiji KM, Stanley CN, Ekanem ES. Evaluation of anti-cholesterol activity of ethyl acetate and $n$-hexane extracts of Tetracarpidium conophorum (Mull. Arg.) Hutch and Dalziel (African walnut) towards hypercholesterolemic rats. Int J Pharm and Phytochem Res 2016; 8: 1372-1376

[10] Ayoola PB, Adeyele A, Onawumi OOP. Phytochemical and nutrient evaluation of Tetracarpidium conophorum (Nigeria walnut) root. Int J Res Rev App Sci 2011; 7: 197-208

[11] Oriakhi K, Uadia PO, Eze IG. Hepatoprotective potential of methanol extract of T. conophorum seeds of carbon tetrachloride induced liver damage in Wistar rats. Clin Phytosci 2018; 4: 25

[12] Uadia PO, Oriakhi K, Osemwenkae PO, Emokpae A. Effect of methanolic extract of Tetracarpidium conophorum seed on haematological parameters in carbon tetrachloride administered albino rats. Nig J Biochem Mol Bio 2012; 27: 63-65 
[13] Akomolafe SF, Oboh G, Akindahunsi AA, Afolayan AJ. Ethanol-induced male infertility: Effects of aqueous leaf extract of Tetracarpidium conophorum. Andrologia 2017; 12759: 1-14

[14] Ajaiyeoba EO, Fadare DA. Antimicrobial potential of extracts and fractions of the African walnut-Tetracarpidium conophorum. Afri J Biotechnol 2006; 5: 2322-2325

[15] Herbert JR, Hurley TG, Olendzki BC, Olendzki BC, Teas J, Ma Y, Hampl JS. Nutritional and socioeconomic factors in reaction to prostate cancer mortality: a cross-national study. J Natl Cancer Inst 1998; 90: 1637-1647

[16] Asgary S, Sahebkar A, Afshani MR, Keshvari M, Haghjooyjavanmard S, Rafieian-Kopaei M. Clinical evaluation of blood pressure lowering, endothelial function improving, hypolipidemic and anti-inflammatory effects of pomegranate juice in hypertensive subjects. Phytother Res 2014; 28: 193-199

[17] Zheng S, Hoos L, Cook J, Tetzioff G, Davis H, Van Heek M, Hwa J. Ezetimibe improves high fat and cholesterol diet-induced non-alcoholic fatty liver disease in mice. Eur J Pharmacol 2008; 584: 118-124

[18] Fukuda T, Ito H, Yoshida T. Antioxidative polyphenols from walnuts (Juglans regia L.). Phytochem 2003; 63: 795-801

[19] Xia D, Wu X, Yang Q, Gong J, Zhang Y. Anti-obesity and hypolipidemic effects of a functional formula containing Prumus mune in mice fed high fat diet. Afri J Bio 2010; 9: 2463-2467

[20] Sibbett SG. Edible tree nuts, walnuts. Encyclopedia of Agricultural Science. 1994; 2: 9-16

[21] Carmena R, Duriez P, Fruchart JC. Atherogenic lipoprotein particles in atherosclerosis. Circulation 2004; 109: 1112-1117

[22] Bhatnagar D, Soran H, Durrington PN. Hypercholesterolaemia and its management. BMJ 2008; 337: 993

[23] Chaudhari HS, Bhandari U, Khanna G. Preventive effect of embelin from Embelia ribes on lipid metabolism and oxidative stress in high-fat diet-induced obesity in rats. Planta Med 2012; 78: 651-657

[24] Natarajan S, Glick H, Criqui M, Horowitz D, Lipsitz SR, Kinosian B. Cholesterol measures to identify and treat individuals at risk for coronary heart disease. Am J Preventive Med 2003; 25: 50-57

[25] Kannel WB. Risk stratification of dyslipidemia: insights from the Framingham Study. Curr Med Chem Cardiovasc Hematol Agents 2005; 23: $187-193$

[26] Fernandez ML, Webb D. The LDL to HDL cholesterol ratio as a valuable tool to evaluate coronary heart disease risk. J Am Coll Nutr 2008; 27: $1-5$

[27] Burge JS, Espenshade PJ. Regulation of HMG-CoA reductase in mammals and yeast. Prog Lipid Res 2011; 50: 2003

[28] Wilson J, Gelb A. Free radicals, antioxidants and neurologic injury: possible relationship to cerebral protection by anesthetics. J Neurosurg Anesthesiol 2002; 14: 66-79
[29] Boroumand N, Samarghandian S, Hashemy SI. Immunomodulatory, anti-inflammatory, and antioxidant effects of curcumin. J Herb Med Pharmacol 2018; 7: 211-219

[30] Uadia PO, Oriakhi K, Osemwenkae PO, Emokpae MA. Phytochemical screening and antioxidant capacity of methanolic extract of Tetracarpidium conophorum seeds. Nig J Biochem Mol Bio 2012; 27: 16-26

[31] Adams RP. Identification of essential oil components by gas chromatography/mass spectrometry. 4th ed. Carol Stream, IL, USA: Allured Publishing Corporation; 2007

[32] NIH Guidelines for the care and use of laboratory animals. NIH publication No. 85-23, Revised 1985. https:/grants.nih.gov/grants/ olaw/guide-for-the-care-and-use-of-laboratory-animals_prepub.pdf

[33] Reeves PG, Nielsen FH, Fahey GC. AIN-93 purified diets for laboratory rodents: final report of the American Institute of Nutrition ad hoc writing committee on the reformulation of the AIN-76A rodent diet. J Nutr 1993; 123: 1939-1951

[34] Allain CC. Enzymatic determination of total serum cholesterol. Clin Chem 1974; 20: 470-475

[35] Lopes-Virella MF, Stone P, Ellis S, Colwell JA. Cholesterol determination in high-density lipoproteins separated by three different methods. Clin Chem 1977; 23: 882-884

[36] Fruchart JC. Separation of low-density lipoprotein and determination of cholesterol and phospholipids bound to the fraction. French J Lab 1982; 103: 7-17

[37] Bucolo G, David H. Quantitative determination of serum triglycerides by the use of enzymes. Clin Chem 1973; 19: 476-478

[38] Rao VA, Ramakrishnan S. Indirect assessment of hydroxymethylglutaryl CoA reductase (NADPH) activity in liver tissue. Clin Chem 1975; 21: 1523-1525

[39] Varshney R, Kale RK. Effect of calmodulin antagonists on radiationinduced lipid peroxidation in microsomes. Int J Rad Bio 1990; 58: 733-743

[40] Habib MR, Nikkon F, Rahman M, Haqui ME, Karim MR. Isolation of stigmasterol and $\beta$-sitosterol from methanolic extract of root bark of Calotropis gigantean (Linn). Pak J Biol Sci 2007; 10: 4174-4176

[41] Jamal AK, Yaacob WA, Din LB. A chemical study on Phyllanthus columnaris. Eur J Sci Res 2009; 28: 76-81

[42] Moghaddam FM, Farimani MM, Salahvarzi S.Gholamreza Chemical Constituents of Dichloromethane Extract of Cultivated Satureja khuzistanica. Evid Based Complement Alternat Med 2007; 4: 95-98

[43] Zhao JL, Liu P, Duan JA, Guo S, Wang X, Sun GT, Yao X, Qian YF. Chemical constituents from root barks of Ginkgo biloba (I). China Tradit Herb Drugs 2013; 44: 1245-1247 